\title{
On Salix-associated Polyporus pseudobetulinus and P. choseniae in Russia
}

\author{
IVAN V. ZMITROVICH, OLEG N. EZHOV and ROMAN V. ERSHOV
}

\begin{abstract}
ZMITROVICH, I.V., EZHOV, O.N. \& ERSHOV, R.V. 2010: On Salix-associated Polyporus pseudobetulinus and P. choseniae in Russia. - Karstenia 50: 53-58. Helsinki. ISSN 0453-3402.

New records of Polyporus pseudobetulinus on willow species from Arkhangelsk Region (North of European Russia) were made. The differences between P. pseudobetulinus and the similar $P$. choseniae are generalized, highlighting spore variability and hyphal system. The two species are rather distant from each other. P. pseudobetulinus is characterized by dimitic hyphal system with a predominance of fibre hyphae, lack of clamps, and somewhat sigmoid spores, whereas $P$. choseniae has dimitic hyphal system with a predominance of skeleto-binding hyphae, clamps, and symmetrically fusoid basidiospores. The ecological preferences and distribution patterns of both species are discussed.
\end{abstract}

Key words: European Russia, Polyporus, salicicolous, morphometry, taxonomy

Ivan V. Zmitrovich, V.L. Komarov Botanical Institute, 2 Popov Street, 197376 St. Petersburg, Russia; e-mail: iv_zmitrovich@mail.ru

Oleg N. Ezhov \& Roman V. Ershov, Institute of Ecological Problems of the North, 23 North Dvina quay, 163000 Arkhangelsk, Russia; e-mail: eon_2006@mail.ru

\section{Introduction}

Polyporus pseudobetulinus (Murashk. ex Pilát) Thorn, Kotir. \& Niemelä (Agaricomycetes, Polyporaceae) is a rare boreal polypore species (Thorn et al. 1990, Kotiranta \& Niemelä 1996, Martikainen et al. 2000) which is presumably associated with Populus spp., mainly P. tremula. During analysis of material collected by the authors in Arkhangelsk Region (North of European Russia), specimens associated with P. balsamifera and Salix caprea were found. Especially the latter is a rather unusual substrate for P. pseudobetulinus. A similar species with Palearctic distribution, P. choseniae (Vassilkov) Parmasto, is reported from Salix spp., including Salix (Chosenia) arbutifolia (Vassilkov 1967; Parmasto 1975). Since these two salicicolous polypores have not been intercompared in the literature, and the second one is little-known to European mycologists, the present study aims to a compar- ative analysis of morphology and ecology of $P$. pseudobetulinus and P. choseniae.

\section{Material and methods}

Microscopical study of basidiomata was carried out as described by Gilbertson \& Ryvarden (1986). Freehand sections and squash mounts were examined in $5 \% \mathrm{KOH}$ and $2 \%$ Cotton Blue. Spore measurements are based on 30 spores per specimen. The following abbreviations are used: $\mathrm{L}=$ spore length, $\mathrm{W}=$ spore width, $\mathrm{Q}^{*}=$ quotient of the mean spore length and mean spore width $(\mathrm{L} / \mathrm{W})$. Specimens are preserved in the herbaria of Komarov Botanical Institute (LE) and Institute of North Ecology (AR).

\section{Descriptions of species}

Polyporus choseniae - Fig. 1, 2, 5a

Polyporus choseniae (Vassilkov) Parmasto (as 'chozeniae'), Folia Cryptog. Estonica 5: 35. 1975 ('1974'). 
$\equiv$ Piptoporus choseniae Vassilkov, Novosti sistematiki nizshikh rastenii 4: 244. 1967.

Basidiomata annual, 4-9 cm diam, 0.5-1.5 cm thick, initially conchate, then convex, solitary or clustered, substipitate or attached to the substrate by a clearly pointed base. Upper surface initially uneven, regularly dotted near the base and radially fibrillose near the margin, initially yellowish-cream, then intensively ochraceous. Margin concolorous, radially fibrillose, initially straight, then incurved. Hymenophore a single tube layer, $0.5-4(-5) \mathrm{mm}$ thick, weakly differentiated from context; pore surface initially yellowish cream, then sordid yellow with a bright pruina over pore margins; pores $1-4$ per $1 \mathrm{~mm}$, roundish, of regular shape and size. Context $0.5-1.7 \mathrm{~cm}$ thick, fleshy when fresh, drying suberose-coriaceous, white. Hyphal system dimitic with skeletobinding hyphae. Generative hyphae 1.5-3 $\mu \mathrm{m}$ diam, clamped, regularly branched, hyaline, thin-walled. Skeletal hyphae of three types: 1) regularly dichotomously branched, $2.5-12.5 \mu \mathrm{m}$ diam (diameter falls to dendrite periphery); 2) their arboriform appendages $2-15 \times 1-3.5 \mu \mathrm{m}$; 3) fibre-like, mainly $2-5 \mu \mathrm{m}$ diam, coiled, subsolid. Cystidia none. Basidia 20-40 × 5.5-7 $\mu$, clavate, four-spored, with a basal clamp. Spores $8-11.7 \times 3.1-4.7 \mu \mathrm{m}\left(\mathrm{Q}^{*}=2.5\right)$, symmetrically fusoid with a short apiculus, smooth, thin-walled, acyanophilous, with oil-rich contents.

On dying and dead trunks of Salix-species in Siberia and occasionally in Mediterranean Europe.

Specimens studied: RUSSIA. Magadan Reg. On Salix arbutifolia, 16.VIII.1965 Vassilkov (LE 22545, typus). Irkutsk Reg. Kashelnikovsky Distr., on S. arbutifolia, 10.VIII.1969 Nezdominogo (two collections, LE 30505, 30506).

\section{Polyporus pseudobetulinus - Fig. 3, 4, 5b}

Polyporus pseudobetulinus (Murashk. ex Pilát) Thorn, Kotir. \& Niemelä, Mycologia 82(5): 583. 1990.

$\equiv$ Ungulina pseudobetulina Murashk. ex Pilát, Bull. Soc. Mycol. France 48: 23. 1932.

$\equiv$ Piptoporus pseudobetulinus (Murashk. ex Pilát) Pilát, Atl. Champ. Eur. 3: 123. 1937.

$\equiv$ Royoporus pseudobetulinus (Murashk. ex Pilát) A.B. De, Mycotaxon 69: 139. 1998.

Basidiomata annual, 4-15(-25) cm diam, $1-4.5 \mathrm{~cm}$ thick, initially ungulate, then convex, solitary or paired, attached to the substrate by a slightly pointed base of subdorsal localization. Upper surface initially subtomentose, then naked and covered by thin cuticle, which can crack to areolate scales, cream with orange or (later) hazel with grayish tints. Margin concolorous, radially fibrillose, initially straight, then incurved. Hymenophore a single tube layer, 1-3(-10) $\mathrm{mm}$ thick, weakly to sharply differentiated from context; pore surface initially whitish, then creamish-orange to pale grey; pores $0.2-3$ per $1 \mathrm{~mm}$, irregular in shape and size, often sinuose and splitted. Context 1 to $3.5 \mathrm{~cm}$ thick, fleshy when fresh, drying spongiose-coriaceous, white to cream. Hyphal system dimitic. Generative hyphae $1.5-5 \mu \mathrm{m}$ diam, simple-septate, rarely branched, hyaline, thin-walled. Skeletal hyphae of two types: 1) regularly dichotomously branched, $2.5-14.5 \mu \mathrm{m}$ diam. (diameter falls to dendrite periphery), rather rarely present in context; 2) fibre-like, mainly 2-6 $\mu \mathrm{m}$ diam, coiled, subsolid, predominant in tube trama and context. Cystidia none. Basidia 18-35(-40) $\times 5-7$ $\mu \mathrm{m}$, clavate, four-spored, efibulate. Spores $(5.5$ )6-9(-11) × 2.4-3.5 $\mu \mathrm{m}\left(\mathrm{Q}^{*}=2.3-3.4\right)$, slightly amygdaloid, ventrally flattened with a prominent, asymmetric apiculus, smooth, thin-walled, acyanophilous, with homogeneous contents.

On dying and dead trunks of Populus and Salix-species (mainly on Populus tremula), throughout the Holarctic. Produces white rot.

Specimens studied: RUSSIA. Krasnoyarsk Reg. On Populus tremula, 27.VI.1959 Yavorsky (LE 208400). Novosibirsk Reg. Suzun forest economy, on $P$. tremula, VII.1964 Zhukov (LE 30512). Leningrad Reg. On P. tremula, 1936 Bondartsev (LE 30508). Archangelsk Reg. Koriazhma Distr., on S. caprea, 01.VIII.2008 Ezhov(AR 1387); on S. caprea, 03.VIII.2009 Ezhov(AR 710); on S. caprea, 03.VIII.2009 Ezhov (LE 269606); on P. balsamifera, 05.VIII.2009 Ezhov (AR 1239). Pinega Distr., Pinega Res., on P. tremula, 19.IX.2007 Ezhov (AR 709). Velsk Distr., on P. tremula, 04.XI.2006 Ershov (AR 711).

\section{Discussion}

The macroscopical differences between the two species have been interpreted controversially in the literature, especially pileus and pore characteristics (Table 1). The clear microscopical differences between the two species are the absence of clamp-connections in cultures of $P$. pseudobetulinus (Thorn et al. 1990) and spore shape and 
size (Thorn 2000). The results of our comparative analysis, including also Salix-associated specimens of $P$. pseudobetulinus from the Arkhangelsk Region, are presented in Table 1. As seen from the material presented, all the Arkhangelsk findings on unusual substrata should be attributed to P. pseudobetulinus. During the present study, also additional data for delimitation of the two species was revealed.

Cap surface. Both species have a cutis. However, in $P$. choseniae regular dots in the cutis appear in earlier stages of basidiome development. These gelatinized areas are more intensively coloured. The colour varies from pale to ochraceous brown. The arrangement of the dots is tessulate near the base and radial near the margin, where cutis cracks radially with linearily arranged dots. The cutis in $P$. pseudobetulinus stays uncracked for rather long, and initial cracking area is associated with part near the base. As a result, the scales are large, areolate and rather rare; there are also specimens with uncracked cuticle devoid of scales.

Base of basidiome. Basidiomata of P. choseniae have a more prominent base, slightly decurrent from the hymenophoral side. However, the point of attachment is minute and often dorsally placed, and thus such decurrency is rather false. $P$. pseudobetulinus has a similar trend when young. In the most cases its basidiomata haven't this false decurrency, bearing a subdorsal base, like those of Piptoporus betulinus (Bull.) P. Karst.

Margin. The margin in both species is poorly differentiated from the hymenophore (in contrast to $P$. betulinus). However, on terminal stages of basidiome development it can be turned inside, appearing as rounded.

Hymenophore. The hymenophore in both species is a single tube layer varying from 1 to 5 (10) $\mathrm{mm}$ in thickness. Tube trama is more gelatinized than outer tissues. The pores of $P$. choseniae are smaller and rather regular, whereas $P$. pseudobetulinus is characterized by larger and irregular pores, which can split like in $P$. betulinus. The colour is sordid yellow in $P$. choseniae and cream with orange tint in P. pseudobetulinus (old specimens of both species are characterized by greyish pruina at the pore margin).

Hyphal system. The hyphal system in both species can be characterized as dimitic with skeleto-binding hyphae. In tube trama of $P$. cho- seniae, together with rather standard dichotomous skeleto-binding hyphae, we found narrow binding-like appendages of robust skeletals. These appendages are highly similar to those in some trametoid polypores, like Perenniporia, Trametes, and Ganoderma. They are abundant in all examined sections. Formally, such a hyphal system should be classified as trimitic. However, this term is rather ambiguous ( $\mathrm{Zm}$ itrovich et al. 2009). We use the term "dimitic with skeleto-binding hyphae" in a wide sense. The terminations of skeleto-binding hyphae in $P$. choseniae appear as coiled, fibre-like skeletals (Fig. 2).

Both tube trama and context of P. pseudobetulinus is composed of regular, coiled fibre hyphae (Fig 4). The ramified skeleto-binding bodies are occasionally dispersed within tissue. Therefore, such a structure is intermediate between Polyporus- and Piptoporus-types (the second type is characterized by total substitution of skeletobinding bodies by fibre-like remnants, as it was shown by Corner 1984).

Spore characteristics. Spore shape and dimensions are clearly different (Fig. 5). Spores of $P$. chozeniae are symmetrically fusoid (boletinoid according to Thorn 2000) with a short apiculus. Their shape and proportions are rather stable (Q* varies around 2.5). Spores of P. pseudobetulinus are slightly amygdaloid, ventrally flattened and with a prominent, asymmetric apiculus (suilloid in bolete terminology). Their propotions are more variable $\left(\mathrm{Q}^{*}\right.$ varies between $\left.2.3-3.4 \mu \mathrm{m}\right)$. They are also smaller and more attenuated.

Generic affiliation. Both species were initially attributed to the genus Piptoporus P. Karst. due to their apodate, seasonal basidiomata with subdorsal attachment. They were later transferred to Polyporus Adans. The reasons were the presence of a "short stipe" in P. choseniae (Parmasto 1975) and the production of white rot by P. pseudobetulinus (Thorn et al. 1990). Some years later, the latter species was transferred to Royoporus A.B. De (De 1998) due to the absence of clamps on generative hyphae. We don't follow this action since clampless representatives of Polyporus are obviously related to various clamped kins and cannot be allocated in a separate unit ( $P$. badius is connected to P. melanopus -group, P. brasiliensis to $P$. arcularius-group, $P$. pseudobetulinus to $P$. admirabilis -group). P. choseniae seems not to be closely related to $P$. pseudobetulinus. It is 
Table 1. Characteristics of Polyporus choseniae and P. pseudobetulinus.

\begin{tabular}{|c|c|c|c|c|c|c|c|}
\hline \multirow{2}{*}{$\begin{array}{l}\text { Species \& } \\
\text { specimens }\end{array}$} & \multirow{2}{*}{ Substrate } & \multirow{2}{*}{$\begin{array}{c}\text { Pores per } \\
\mathrm{mm}\end{array}$} & \multirow{2}{*}{ Scales } & \multicolumn{3}{|c|}{ Spores characteristics } & \multirow{2}{*}{ Clamp } \\
\hline & & & & $\mathrm{L}, \mu \mathrm{m}$ & $\mathrm{W}, \mu \mathrm{m}$ & $\mathrm{Q}^{*}$ & \\
\hline \multicolumn{8}{|c|}{ Species descriptions in literature } \\
\hline $\begin{array}{l}\text { P. choseniae } \\
\text { (Vassilkov 1967) }\end{array}$ & S. arbutifolia & $1-3$ & spot-like & $10-12.5$ & 5.0 & 2.2 & $\begin{array}{l}\text { no men- } \\
\text { tion }\end{array}$ \\
\hline $\begin{array}{l}\text { P. choseniae } \\
\text { (Parmasto 1975) }\end{array}$ & Salix spp. & $3(4)$ & $\begin{array}{l}\text { spot-like, } \\
0.2-0.4(0.8) \\
\text { mm diam. }\end{array}$ & $10.6-11.7$ & $4.3-4.5$ & 2.5 & + \\
\hline $\begin{array}{l}\text { P. choseniae } \\
\text { (Bondartseva 1998) }\end{array}$ & S. arbutifolia & $1-2(3)$ & spot-like & $8.0-10.0$ & $3.0-4.0$ & 2.4 & + \\
\hline $\begin{array}{l}\text { P. choseniae } \\
\text { (Thorn 2000) }\end{array}$ & Salix spp. & $3-4$ & as dark dots & $\begin{array}{c}(8.0-) 9.7- \\
12.2(-13.6)\end{array}$ & $\begin{array}{c}(3.6-) 4.1- \\
5.3(-6.1)\end{array}$ & 2.3 & + \\
\hline $\begin{array}{l}\text { P. pseudobetulinus } \\
\text { (Ryvarden \& } \\
\text { Gilbertson 1994) }\end{array}$ & Populus spp. & $1-3$ & $\begin{array}{l}\text { pileus finely } \\
\text { fibrillose, } \\
\text { becoming are- } \\
\text { olate }\end{array}$ & $\begin{array}{c}(6.5-) 7.2- \\
10.0\end{array}$ & $2.5-3.4$ & 2.9 & - \\
\hline $\begin{array}{l}\text { P. pseudobetulinus } \\
\text { (Bondartseva 1998) }\end{array}$ & P. tremula & $1.5-3$ & spot-like & $\begin{array}{c}6.0-8.0 \\
(-9.0)\end{array}$ & $2.5-3.5$ & 2.4 & \begin{tabular}{|l|} 
no men- \\
tion
\end{tabular} \\
\hline $\begin{array}{l}\text { P. pseudobetulinus } \\
\text { (Thorn 2000) }\end{array}$ & $\begin{array}{l}\text { P. tremula, } P \text {. } \\
\text { balsamifera }\end{array}$ & $3-4$ & \begin{tabular}{|l} 
appressed \\
scales
\end{tabular} & $7.0-9.5$ & $2.5-3.5$ & 2.8 & - \\
\hline \multicolumn{8}{|c|}{ Specimens examined } \\
\hline $\begin{array}{l}\text { P. choseniae } \\
\text { (type, LE 22545) }\end{array}$ & S. arbutifolia & $1.5-4$ & \begin{tabular}{|l} 
regularly dot- \\
ted near the \\
base
\end{tabular} & $8.0-11.7$ & $3.1-4.7$ & 2.5 & + \\
\hline $\begin{array}{l}\text { P. pseudobetulinus } \\
\text { (LE 208400) }\end{array}$ & P. tremula & $0.8-3$ & \begin{tabular}{|l|}
$\begin{array}{l}\text { irregularly } \\
\text { scaled }\end{array}$ \\
\end{tabular} & $5.5-8.0$ & $2.6-3.2$ & 2.3 & - \\
\hline $\begin{array}{l}\text { P. pseudobetulinus } \\
\text { (AR 1387) }\end{array}$ & S. caprea & $0.5-3$ & $\begin{array}{l}\text { irregularly } \\
\text { scaled }\end{array}$ & $6.5-9.1$ & $2.5-3.0$ & 2.8 & - \\
\hline $\begin{array}{l}\text { P. pseudobetulinus } \\
\text { (LE 269606) }\end{array}$ & S. caprea & $0.2-2.5$ & $\begin{array}{l}\text { irregularly } \\
\text { scaled }\end{array}$ & $7.8-10.9$ & $2.4-3.1$ & 3.4 & - \\
\hline $\begin{array}{l}\text { P. pseudobetulinus } \\
\text { (AR 710) }\end{array}$ & S. caprea & $1-3$ & $\begin{array}{l}\text { irregularly } \\
\text { scaled }\end{array}$ & $5.5-8.1$ & $2.5-2.9$ & 2.5 & - \\
\hline $\begin{array}{l}\text { P. pseudobetulinus } \\
\text { (AR 1239) }\end{array}$ & P.balsamifera & $0.5-2$ & $\begin{array}{l}\text { practically } \\
\text { without scales }\end{array}$ & $6.5-7.8$ & $2.8-3.0$ & 2.5 & - \\
\hline $\begin{array}{l}\text { P. pseudobetulinus } \\
\text { (AR 711) }\end{array}$ & P. tremula & $2-3$ & $\begin{array}{l}\begin{array}{l}\text { irregularly } \\
\text { scaled }\end{array} \\
\end{array}$ & $6.3-9.1$ & $2.5-3.0$ & 2.8 & - \\
\hline
\end{tabular}

more probable that the species represents a certain branch of $P$. varius-group.

Ecology and distribution. P. pseudobetulinus prefers to colonize dead, standing wood of Populus tremula (Bondartsev 1953, Bondartseva 1998, Martikainen et al., 2000). It can also infest other Populus species and rarely Salix spp. (Núñez \& Ryvarden 1995, Thorn et al., 2000, Schigel 2009). As a rule, host trees are rather old, and the fungus favours old-growth forests but can also be found on retained aspens in clearcut areas (Martikainen et al. 2007, Andersson et al. 2009, Schigel 2009). Our collections on $S$. caprea and $P$. balsamifera were made on dying trees near the ground. Usually the species occurs higher, ca. 3-5 $\mathrm{m}$ above the ground. The species has a Holarctic distribution following the distribution of P. tremula and Salix spp.

The data on substrate preference and distribution of $P$. choseniae is scarce. It was described from Russian Far East (Vassilkov 1967), where it was associated with Salix (Chosenia) arbutifolia. It was collected time to time on other Salix species in Central and South Siberian regions. It 


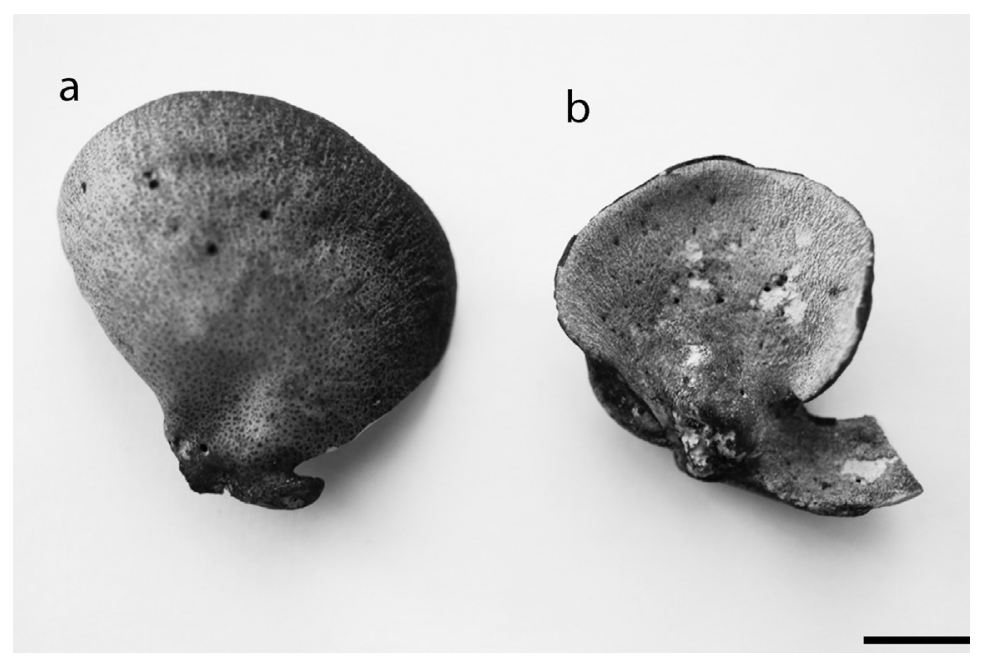

Fig. 1. Polyporus choseniae (type material). $\mathrm{a}=$ dotted and radially fibrillose upper surface; $b=$ hymenophoral surface. Scale = $1 \mathrm{~cm}$.

was also reported from Mediterranean Europe (Krisai-Greilhuber \& Ryvarden 1997).

Acknowledgments: Financial support from RFBR grants "Regularities of mycobiota formation of boreal forests on North-West of Russia in cretaceous landscapes environments" (N 08-04-98805-p north a) and "Substrate preference and spatial structure of biota of aphyllophoroid fungi in nature ecosystems of European Russia" (09-0401064-a).

\section{References}

Andersson, L., Alekseeva N.M. \& Kuznetsova E.S. (eds.) 2009: Vyjavlenie i obsledovanie biologicheski tsennykh lessov na Severo-Zapade Evropeiskoi chasti Rossii. T. 2. Posobie po opredeleniyu vidov, ispolzuemykh pri obsledovanii na urovne vydelov [The revealing and observation of biologically valued forests on North West of European part of Russia. T. 2. A handbook on species used in observations in stratum level]. -258 pp. St. Petersburg.

Bondartsev, A.S. 1953: Trutovye griby Evropeiskoi chasti SSSR i Kavkaza [The Polyporaceae of the European part of URSS and Caucasia]. - 1106 pp. Acad. Publ., Moscow, Leningrad.

Bondartseva, M.A. 1998: Opredelitel' gribov Rossii. Poryadok afilloforovye. Vypusk 2 [The handbook on fungi of Russia. Order Aphyllophorales. Ser. 2]. - 391 pp. Acad. Publ., St Petersburg.

Corner, E.J.H. 1984: Ad Polyporaceas II \& III. Polyporus, Mycobonia, and Echinochaete. Piptoporus, Buglossoporus, Laetiporus, Meripilus, and Bondarzewia. - Beihefte, Nova Hedwigia 78: 1-222.

De, A.B. 1998: Taxonomy of Royoporus pseudobetulinus comb. nov. - Mycotaxon 69: 137-143.
Gilbertson, R.L. \& Ryvarden, L. 1986: North American polypores. 1. -436 pp. Fungiflora, Oslo.

Kotiranta, H. \& Niemelä, T. 1996: Uhanalaiset käävät Suomessa. - Ympäristöopas 10: 1-184. [In Finnish with English summary].

Krisai-Greilhuber, I. \& Ryvarden, L. 1997: Polyporus chozeniae: a boreal polypore, new for Europe. - Boll. Gr. micol. G. Bres. 40: 281-284.

Martikainen, P., Penttilä, R., Kotiranta, H. \& Miettinen, O. 2000: New records of Funalia trogii, Perenniporia tenuis and Polyporus pseudobetulinus from Finland, with notes on their habitat requirements and conservation implications. - Karstenia 40: 79-92.

Núñez, M. \& Ryvarden, L. 1995: Polypores, new to Japan 1. Species of Polyporus, with a note on P. hartmanni. Mycoscience 36: 61-65.

Parmasto, E. 1975 ('1974'): On Polyporus chozeniae (Vassilk.) Parm. comb. nov. and related species. - Folia Cryptog. Estonica 5: 35-39.

Ryvarden, L. \& Gilbertson, R.L. 1994: European polypores. Part. 2. - 743 pp. Fungiflora, Oslo.

Schigel, D.S. 2009. Polypore assemblages in boreal oldgrowth forests, and associated Coleoptera.- $50 \mathrm{pp}$. Academic dissertation. Helsinki, 2009.

Thorn, R.G. 2000: Some polypores misclassified in Piptoporus. - Karstenia 40: 181-187.

Thorn, R.G., Kotiranta, H. \& Niemelä, T. 1990: Polyporus pseudobetulinus comb. nov.: new records in Europe and North America. - Mycologia 82: 582-594.

Vassilkov, B.P. 1967: Novyi vid trutovikovogo griba na chozenii. [Species nova familiae Polyporaceae in Chosenia macrolepis (Turcz.) Kom.]. - Novosti sistematiki nizzhikh rastenii 4: 244-246.

Zmitrovich, I.V., Malysheva, V.F. \& Malysheva, E.F. 2009: Tipy gif poliporoidnykh i plevrotoidnykh gribov: terminologicheskaya revisiya. [The types of hyphae of polyporoid and pleurotoid fungi: a terminology revision]. - Ucrainian Botanical Journal 66(1): 71-81. 


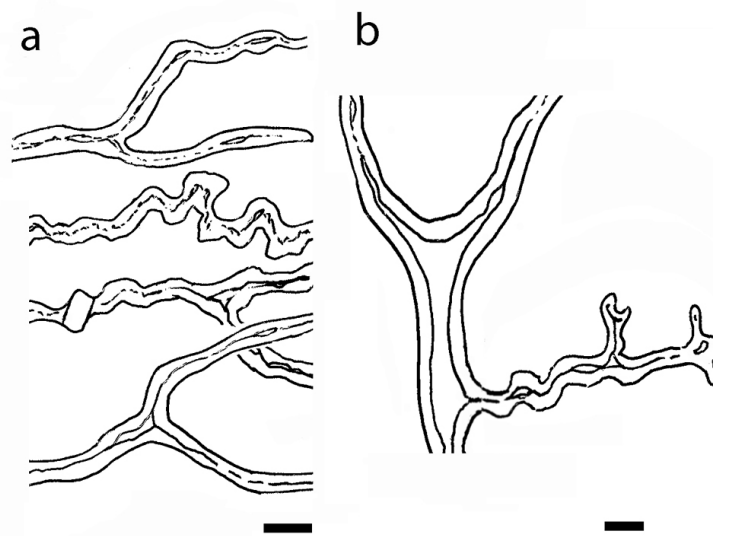

Fig. 2. Skeletal hyphae in Polyporus choseniae. $\mathrm{a}=$ skeleto-binding hyphae with coiled fibre terminals. $\mathrm{b}=$ skeleto-binding hypha with arborifom appendage. Scale $=10 \mu \mathrm{m}$.

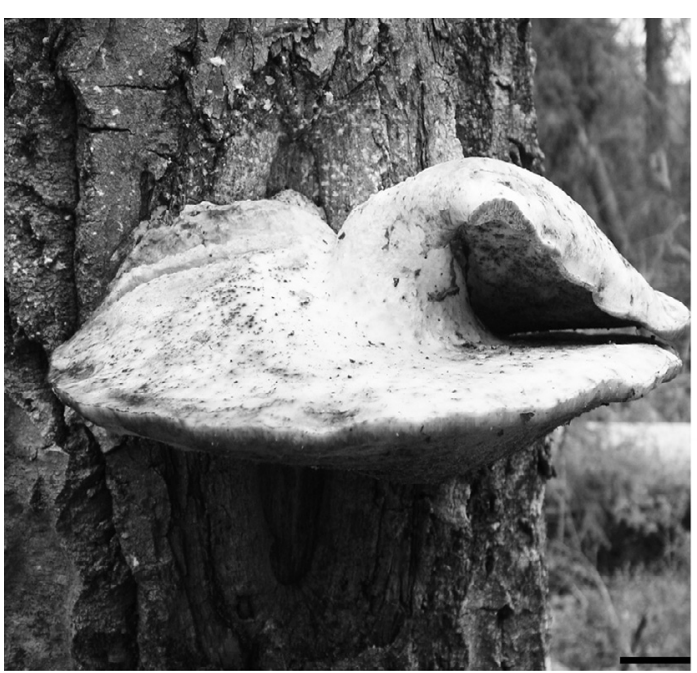

Fig. 3. Polyporus pseudobetulinus. Scale $=1 \mathrm{~cm}$.

Fig. 4. Skeletal hyphae of Polyporus pseudobetulinus. $\mathrm{a}=$ coiled fibre hyphae, predominant in the basidiome. $\mathrm{b}=$ dichotomously branched skeleto-binding hyphae, initial to fibre skeletals. Scale $=10 \mu \mathrm{m}$. a

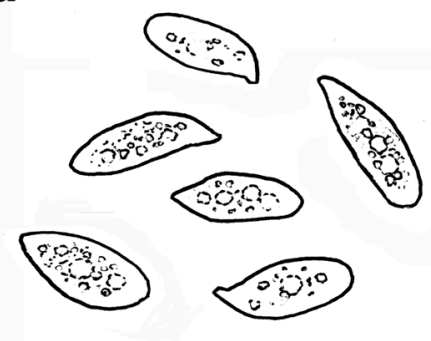

b
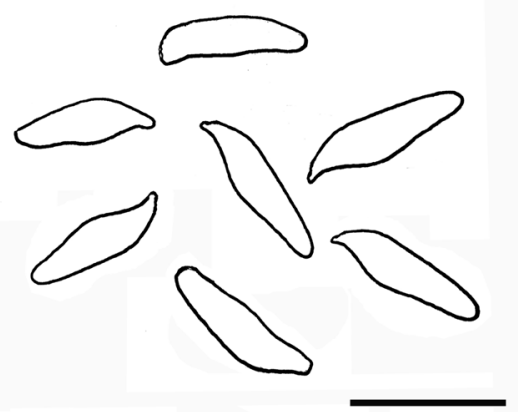

Fig. 5. Basidiospores of Polyporus choseniae (a) and $P$. pseudobetulinus (b). Scale = $10 \mu \mathrm{m}$. 